\section{ECONOMICS}

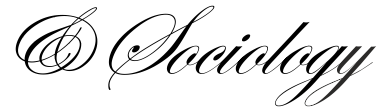

\title{
SOCIO-ECONOMIC DEVELOPMENT OF AGRICULTURAL PROBLEM AREAS IN POLAND
}

\begin{abstract}
This article attempts to identify a relation between several local development factors and localization of agricultural problem areas in Poland, which include areas with limited potential for proper agricultural production, i.e., adverse soil and climatic conditions, severe soil degradation processes and fragmented structure of land. Such conditions consequently lead to low competitiveness of farms located there as well as bad demographic structure, depopulation and peripheral developmental position of the gminas. To assess levels of development, 6 detailed measures are constructed, using Hellwig's synthetic measure. The final measure, grouping 17 variables, presents spatial distribution of the level of socio-economic development of selected 73 most problem gminas in Poland.
\end{abstract}

DOI: $10.14254 / 2071-$

789X.2014/7-2/18

JEL Classification: J10, O18,

Keywords: rural areas, local development, agricultural production, P48, R15, R23, R51

\section{Introduction}

Agricultural problem areas include areas with limited potential for proper agricultural production, i.e., adverse soil and climatic conditions, severe soil degradation processes and fragmented structure of land, which consequently leads to low competitiveness of farms located there. In addition, these areas are exposed to marginalization and disturbance of social processes (http://opr.iung.pulawy.pl/index.html?st=def, access: 03/22/2014).

On the one hand, modernizing agriculture reduces demand for labour and consequently leads to either reduction in employment or overgrowth (Rosner, 2012, p. 14). On the other hand, areas with low competitiveness of agriculture tend to depopulation - they have been left especially by young and educated people. There is also a preponderance of men over women (see: Rakowska, 2011a, p 9). The observed low values of feminization indices do not help natural increase and improvement of the demographic structure of these areas. An important role should be played by local authorities, creating some incentives for potential entrepreneurs and immigrant population (see: Dziemianowicz, Swianiewicz, 2007; Misterek, 2011).

According to the Institute of Soil Science and Plant Cultivation (IUNG) research (http://opr.iung.pulawy.pl/index.html?st=def, access: 03/22/2014), agricultural problem areas 
include areas meeting at least one of the following conditions (factors limiting proper agricultural production):

- fragmentation of farms (average farm area 1-10 ha, more than 4 plots, average plot area smaller than 2.5 ha),

- included in LFA area: lowland ( $2^{\text {nd }}$ type), of specific difficulties or mountainous,

- low content of organic matter in soils (less than 1.3\%),

- potential water erosion risk (medium and high level),

- soil acidification $(\mathrm{pH}<4.5)$,

- soil pollution with trace elements.

In fact, maximum number of points reached by a gmina amounts to 4 . The analysis covered 73 the most problem gminas - all gminas with 3 or 4 factors - including 14 with 4 factors and 59 with 3 factors limiting proper agricultural production (see Fig. 1).

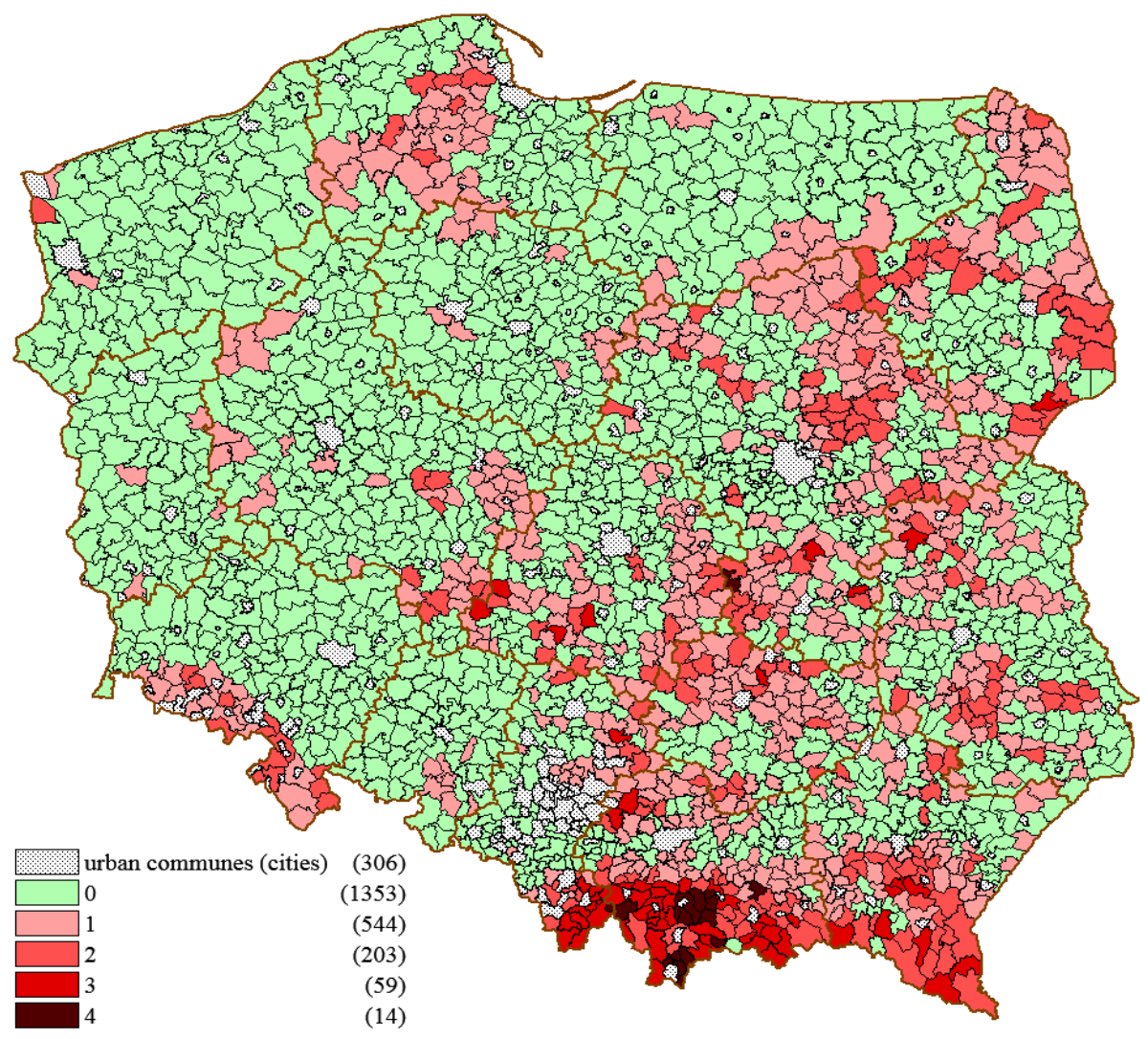

Fig. 1. Problem areas of agriculture regarding number of factors limiting production Source: Author's elaboration based on of the Institute of Soil Science and Plant Cultivation (IUNG) information.

The main objective of the study is to assess socio-economic development of the most problem areas of agriculture in Poland.

\section{Method}

The multidimensional nature of the socio-economic development entails use of synthetic indicators for its level measuring. Considerable Polish literature shows diversity of available development methods and measures. The most popular taxonomic analyses of social or economic development are as following: 
- Hellwig's measure (Gralak, 2005; Feltynowski, 2009; Pomianek, 2010; Czapiewski, 2010; Tarka, 2013; Zimny, 2013);

- method of standardized sum or Perkal's index (Babuchowska, Kisiel, 2006; Feltynowski, 2009; Brodzinski, 2011);

- method of rank sum (Rakowska, 2009, 2011b);

- k-means method (Pietrzykowski, 2009; Chrzanowska, Drejerska, Pomianek, 2013; Tarka, 2013);

- Ward's cluster analysis (Surówka, 2007; Tarka, 2013);

- non-pattern synthetic measure (Krakowiak-Bal, 2005; Ossowska, 2008);

- factor analysis (Tarka, 2013);

- Czekanowski's distance tables (Górka, Chmurska, 2004) etc.

The analysis bases on construction of seven similar measures (and rankings), using Hellwig's synthetic measure (Hellwig, 1968, 1981; Nowak, 1990; Panek, 2009). Six of them are detailed and concern different aspects of local development (Table 1): demographic development, social development, local government potential, local finances structure, entrepreneurship development and technical infrastructure development. The final measure is an aggregated form of the other six measures and presents a complex view of socio-economic level of the most problem areas of agriculture.

Table 1. Variables accepted in the analysis

\begin{tabular}{ccc}
\hline Symbol & Measure 1 - demographic development & Notes \\
\hline \multicolumn{4}{c}{ population density (population per 1 square kilometre) } \\
\hline X1.1 & birth rate (balance of births and deaths per 1,000 population) & stimulant \\
\hline X1.3 & demographic burden (population of post working-age per 100 population \\
of working-age) & stimulant \\
\hline \multicolumn{4}{c}{ Measure 2 - social development } \\
\hline X2.1 & proportion of registered unemployed in the working-age population \\
\hline X2.2 & total balance of migration & destimulant \\
\hline X2.3 & proportion of children aged 3-5 participating in preschool education \\
\hline \multicolumn{4}{c}{ Measure 3 - local government potential } \\
\hline X3.1 & proportion of councillors with university degrees & stimulant \\
\hline X3.2 & proportion of councillors with high professional qualifications \\
\hline \multicolumn{4}{c}{ Measure 4 - local finances structure } \\
\hline X4.1 & gmina's own income per capita & stimulant \\
\hline X4.2 & gtimulant \\
\hline X4.3 & gmina's property investment expenditure per capita \\
\hline \multicolumn{4}{c}{ Measure 5 - entrepreneurship development } \\
\hline X5.1 & national economy entities registered in REGON per 10,000 population \\
\hline X5.2 & natural person running economic activity per 100 working-age population \\
\hline X5.3 & foundations, associations and social organizations per 10,000 population \\
\hline X5.4 & newly registered entities per 10,000 working-age population & stimulant \\
\hline \multicolumn{4}{c}{ Measure 6 - technical infrastructure development } & stimulant \\
\hline X6.1 & proportion of population with water supply connection & stimulant \\
\hline X6.2 & proportion of population with sewerage connection & stimulant \\
\hline \multicolumn{4}{c}{ stimulant } \\
\hline
\end{tabular}

Source: Author's compilation based on CSO LDB information. 
The variables enable to divide gminas into three classes, regarding their levels of development by Hellwig's synthetic measure. Hellwig's synthetic measure of development groups information from a set of diagnostic features and assigns a single (aggregate) measure. The measure is calculated as a synthetic indicator of taxonomic distance of the object from the theoretical pattern of development. The method allows to organize a set of objects (gminas) $P_{\mathrm{i}}$ (where: $i=1,2, \ldots, n$ ), when each of them is described in a set of $m$ diagnostic features: stimulants or destimulants. following:

Description of a set of objects can be presented in the form of the $\mathbf{X}$ matrix as

$$
\mathbf{X}=\left[\begin{array}{cccc}
x_{11} & x_{12} & \ldots & x_{1 m} \\
x_{21} & x_{22} & \ldots & x_{2 m} \\
\ldots & \ldots & \ldots & \ldots \\
x_{n 1} & x_{n 2} & \ldots & x_{n m}
\end{array}\right]
$$

where: $x_{i j}$ - means the $j$-th characteristics of the $i$-th object $(i=1,2, \ldots, n ; j=1,2, \ldots, m)$.

In order to unify the variables, normalization of the characteristics is made by their standardization according to the formula:

$$
z_{i j}=\frac{\left(x_{i j}-\bar{x}_{j}\right)}{S_{j}},(j=1,2, \ldots, m)
$$

As a result, a transformation matrix $(\mathbf{Z})$ of standardized values of the characteristics is obtained:

$$
\mathbf{Z}=\left[\begin{array}{cccc}
z_{11} & z_{12} & \ldots & z_{1 m} \\
z_{21} & z_{22} & \ldots & z_{2 m} \\
\cdots & \ldots & \ldots & \cdots \\
z_{n 1} & z_{n 2} & \ldots & z_{n m}
\end{array}\right]
$$

where: $z_{i j}$ is a standardized value of $x_{i j}$.

The matrix is used to determine the pattern of development, i.e. an abstract object (gmina) $P_{0}$ with standardized coordinates $z_{01}, z_{02}, \ldots, z_{0 j}$, where $z_{0 j}=\max \left\{z_{i j}\right\}$, if $Z_{j}$ is a stimulant or $z_{0 j}=\min \left\{z_{i j}\right\}$, if $Z_{j}$ is destimulant. It follows that the pattern is a hypothetical gmina with the best values of the observed variables.

Then, distance from the pattern for each $P_{i}$ object (gmina) is determined according to the formula:

$$
d_{i}=1-\frac{D_{i o}}{D_{o}}(i=1,2, \ldots, n)
$$

where:

$$
\begin{array}{ll}
D_{i o} & =\sqrt{\sum_{j=1}^{m}\left(z_{i j}-z_{o j}\right)^{2}} \quad \text { (5) } \quad \text { (distance of } i \text {-th object from } P_{o} \text { object) } \\
D_{o} & =\bar{D}_{o}+2 S_{o} \quad \text { (6) }
\end{array}
$$




$$
\begin{aligned}
& \bar{D}_{o}=n^{-1} \sum_{i=1}^{n} D_{i o} \\
& S_{o}=\sqrt{n^{-1} \sum_{i=1}^{n}\left(D_{i o}-\bar{D}_{o}\right)^{2}}
\end{aligned}
$$

In this way, synthetic ratings are determined for each gmina. The taxonomic measure $\left(d_{i}\right)$ takes values from the interval $[0,1]$. However, if variables' values are outstanding in relation to a whole population, they do not belong to the typical range of variation (mean standard deviation, mean + standard deviation) and the measure's value can be negative.The more the characteristics of a gmina are similar to the pattern, the level of its development is higher. The classification of gminas according to a level of development uses two parameters: arithmetic mean and standard deviation. Division into the following class intervals is made:

- Class 1 (high level of development) $d_{i}>\bar{d}_{i}+s_{d_{i}}$, grouping gminas which distances from the pattern exceed the value of $\bar{d}_{i}+s_{d_{i}}$,

- Class 2 (medium level of development) $\bar{d}_{i}-s_{d_{i}}<d_{i} \leq \bar{d}_{i}+s_{d_{i}}$, grouping gminas which distances from the pattern ranges in $\left(\bar{d}_{i_{d_{i}}}-s_{d_{i}}, \bar{d}_{i}+s_{d_{i}}\right\rfloor$,

- Class 3 (low level of development) $d_{i} \leq \bar{d}_{i}-s_{d_{i}}$, grouping gminas which distances from the pattern does not exceed the value of $\bar{d}_{i}-s_{d_{i}}$,

where:

$d_{i}$ - Hellwig's synthetic measure value; $\bar{d}_{i}$ - arithmetic mean of $d_{i} ; s_{d_{i}}$ - standard deviation of $d_{i}$.

The analysis requires adoption of data at the LAU-2 level, which is at a communal level in Poland (in literature: gminas, gminas, municipalities). Unfortunately, a great problem is data availability, because the Central Statistical Office does not collect some potentially significant data for LAU 2 level. These are available only at the LAU-1 level (powiats) or even the NUTS-3 level of voivodships (in literature also: provinces, regions), so it would be difficult or even impossible to adopt them to differentiate the level of a particular phenomenon in gminas.

The analysis uses data as of 31.12.2012 (Local Data Bank, Central Statistical Office, Poland, available at: http://www.stat.gov.pl/bdl/app/strona.html?p_name=indeks access: 03/23/2014).

\section{Research results}

The first measure was constructed using three variables: population density, birth rate and demographic burden. These are fundamental demographic indicators, having impact on a local development level. On the one hand, number of population, related to the inhabited area, requires adequate amount of communal services and financing (i.e. schools, transport, safety etc.). On the other hand, the population participates in local budget directly by paying local taxes and fees and indirectly, in the form of some share of PIT (Personal Income Tax) and CIT (Corporate Income Tax) transferred from the national level. The birth rate, as a result of births and deaths as well as population of post working-age per 100 population of workingage, inform of positive or negative tendencies in local society.

The Class 1 (Table 2, Fig. 2) is dominated by gminas from Małopolskie Voivodship: Tymbark, Nawojowa, Olkusz, Biały Dunajec, Kamionka Wielka, Limanowa and Raba 
Wyżna. Two other gminas (Węgierska Górka, Gilowice) are situated in Śląskie Voivodship. On the other hand, in the Class 3, three gminas from Mazowieckie Voivodship have been included: Garbatka-Letnisko, Grabów nad Pilicą, Odrzywół. Moreover, there are two Śląskie gminas (Rajcza, Ujsoły) as well as Cisna from Podkarpackie Voivodship, Kiełczygłów from Łódzkie Voivodship and Kleszczele from Podlaskie Voivodship.

Table 2. Measure 1 - extreme classes of demographic development

\begin{tabular}{cccccc}
\hline Rank & Gmina & Value & Rank & Gmina & Value \\
\hline \multicolumn{7}{c}{ Class 1 } & & \multicolumn{4}{c}{ Class 3 } \\
\hline 1 & Tymbark (r) & 0.627 & 66 & Cisna (r) & 0.166 \\
\hline 2 & Nawojowa (r) & 0.608 & 67 & Garbatka-Letnisko (r) & 0.152 \\
\hline 3 & Olkusz (u-r) & 0.597 & 68 & Grabów nad Pilicą (r) & 0.138 \\
\hline 4 & Gilowice (r) & 0.596 & 69 & Rajcza (r) & 0.111 \\
\hline 5 & Biały Dunajec (r) & 0.594 & 70 & Ujsoły (r) & 0.080 \\
\hline 6 & Kamionka Wielka (r) & 0.577 & 71 & Kiełczygłów (r) & 0.066 \\
\hline 7 & Limanowa (r) & 0.565 & 72 & Odrzywół (r) & 0.044 \\
\hline 8 & Raba Wyżna (r) & 0.564 & 73 & Kleszczele (u-r) & -0.544 \\
\hline 9 & Węgierska Górka (r) & 0.553 & & & \\
\hline
\end{tabular}

Note: $\mathrm{r}$ - rural gmina, u-r - urban-rural gmina

Source: Author's calculation based on CSO LDB information.

Although, as noted above, the Hellwig's measure takes values from 0 to 1 , the value calculated for Kleszczele is negative. It is a symptom of significant standing out in terms of the analysed characteristics compared to other units. The value of X1.2 variable is the lowest, whereas the value of and X1.3 is the highest in the studied group of gminas. The outstanding values do not belong to the typical range of variation (mean - standard deviation, mean + standard deviation). In 2012, the population density amounted to 19 people per square kilometre, whereas the mean for the gminas amounted to as much as 108 people (median 101). Negative natural increase stood at -13 (mean 1.8, median 2.1) and the proportion of population of over working age per 100 population of working age amounted to $59.8 \%$ (mean $25.5 \%$, median 24\%).

The Measure 2 combines three variables: proportion of registered unemployed in the working-age population, total balance of migration and proportion of children aged 3-5 participating in preschool education. There is no information (for the LAU-2 level) on unemployment rate, so the best available characteristics of local labour market concerns number of unemployed inhabitants in relation to all inhabitants of working-age. The variables require special activeness of local government - taking care for unemployed, facilitating and promoting self-employment, and finally - promoting the gmina as an attractive area of living, raising children and running economic activity. 


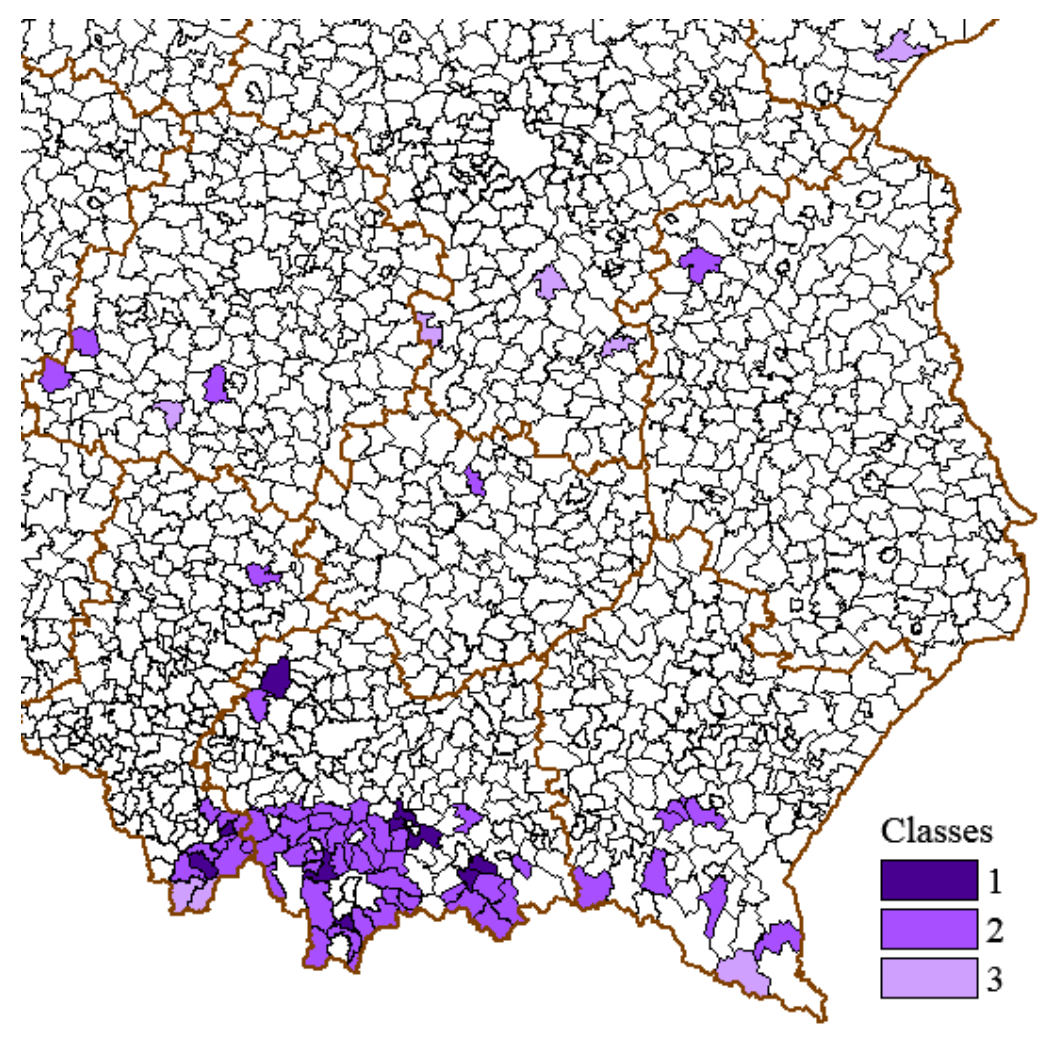

Fig. 2. Measure 1 - classes of demographic development

Source: Author's calculation based on CSO LDB information.

The Class 1 includes as many as 13 gminas: 5 from Śląskie Voivodship (Koszarawa, Czernichów, Ślemień, Świnna, Radziechowy-Wieprz), 6 from Małopolskie Voivodship (Łapsze Niżne, Trzebinia, Wiśniowa, Czarny Dunajec, Pcim, Lubień) and 2 from Łódzkie Voivodship (Brąszewice, Galewice). Another 8 gminas have been classified into the Class 3: 3 from Małopolskie Voivodship (Gródek nad Dunajcem, Limanowa, Olkusz), 4 from Podkarpackie Voivodship (Czarna, Krempna, Nozdrzec, Domaradz) as well as Odrzywół (Mazowieckie Voivodship). Next 5 gminas situated on the bottom of the ranking have been characterised by particularly low values of the variables (Table 3).

This time, as many as 3 gminas have received negative values of Hellwig's measure. In 2012, Olkusz was characterised by the lowest migration balance, amounting to - 195 people (mean -2, median -1). In Domaradz the rank has been a result of the highest proportion of registered unemployed in the working-age population, which amounted to $19.7 \%$ (mean $10 \%$, median $0.3 \%$ ). Finally, Nozdrzec owes its measure's value to relatively high proportion of unemployed $(17.3 \%)$ and low proportion of children aged 3-5 participating in pre-school education (36.8\% compared to mean: $57.8 \%$ and median: $60.3 \%$ ).

Table 3. Measure 2 - extreme classes of social development

\begin{tabular}{cccccc}
\hline Rank & Gmina & Value & Rank & Gmina & Value \\
\hline \multicolumn{7}{c}{ Class 1 } & & & Class 3 & \\
\hline 1 & Koszarawa (r) & 0.686 & 66 & Gródek nad Dunajcem (r) & 0.125 \\
\hline 2 & Czernichów (r) & 0.663 & 67 & Odrzywół (r) & 0.104 \\
\hline 3 & Trzebinia (u-r) & 0.659 & 68 & Limanowa (r) & 0.079 \\
\hline 4 & Ślemień (r) & 0.654 & 69 & Czarna (r) & 0.006 \\
\hline 5 & Wiśniowa (r) & 0.632 & 70 & Krempna (r) & 0.002 \\
\hline
\end{tabular}




\begin{tabular}{cccccc}
\hline 6 & Brąszewice (r) & 0.614 & 71 & Nozdrzec (r) & -0.006 \\
\hline 7 & Czarny Dunajec (r) & 0.602 & 72 & Domaradz (r) & -0.020 \\
\hline 8 & Pcim (r) & 0.599 & 73 & Olkusz (r) & -0.314 \\
\hline 9 & Galewice (r) & 0.598 & & & \\
\hline 10 & Lubień (r) & 0.596 & & & \\
\hline 11 & Radziechowy-Wieprz (r) & 0.579 & & & \\
\hline 12 & Lapsze Niżne (r) & 0.577 & & & \\
\hline 13 & Świnna (r) & 0.567 & & &
\end{tabular}

Note: $\mathrm{r}$ - rural gmina, u-r - urban-rural gmina

Source: Author's calculation based on CSO LDB information.

The spatial distribution of development classes by the Measure 2 is presented in Fig.3.

The next measure (3) presents level of local government potential, basing on two characteristics: proportion of councillors with university degrees and proportion of councillors with high professional qualifications. Moreover, the variables inform of social involvement in local issues (see: Heffner, Rosner, 2002, pp. 136-137). According to studies conducted by A. Rosner and M. Stanny (2007, p. 141) and I. Pomianek (2010), in gminas of low level of socio-economic development high level of education of candidates for councillors may not be a decisive factor for the choice. However, it may suggest also less interest of local population in issues of the gmina, reluctance of better-educated people to sit on the board or just a lower level of education of people living there.

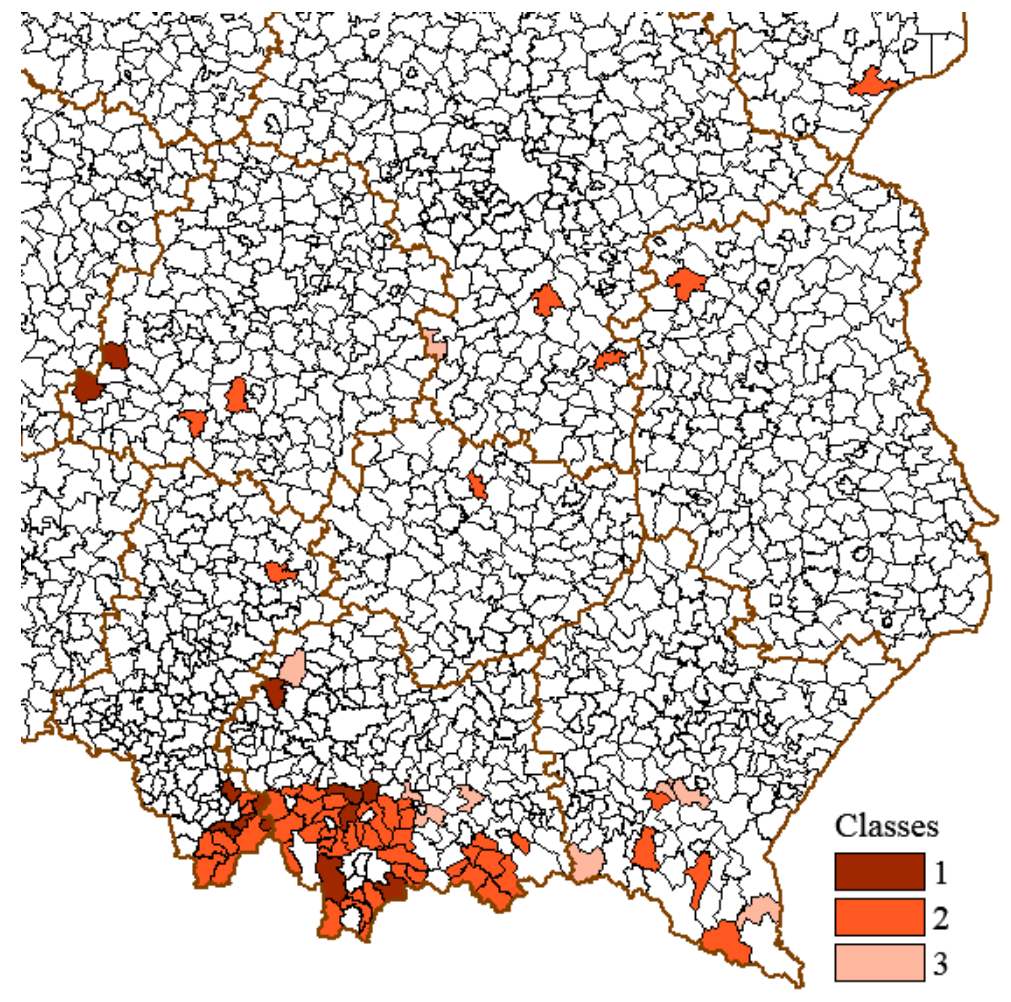

Fig. 3. Measure 2 - classes of social development

Source: Author's calculation based on CSO LDB information.

The Class 1 includes 11 gminas. 7 gminas lay in Małopolskie Voivodship (Olkusz, Krościenko nad Dunajcem, Tymbark, Muszyna, Krynica-Zdrój, Rabka-Zdrój, Gródek nad Dunajcem). Other gminas belong to following voivodships: Podkarpackie (Jasienica Rosielna, 
Zagórz), Śląskie (Węgierska Górka) and Mazowieckie (Garbatka-Letnisko). On the other hand, the Class 3 includes additional 7 gminas from Małopolskie Voivodship (Bukowina Tatrzańska, Zawoja, Czorsztyn, Tokarnia, Nawojowa, Spytkowice, Czarny Dunajec). Three more gminas of low potential of local government lay in following voivodships: Mazowieckie (Grabów nad Pilicą), Łódzkie (Kiełczygłów) and Podkarpackie (Czarna) - see Table 4.

Table 4. Measure 3 - extreme classes of government potential

\begin{tabular}{cccccc}
\hline Rank & Gmina & Value & Rank & Gmina & Value \\
\hline & Class 1 & & & Class 3 & \\
\hline 1 & Olkusz (u-r) & 1.000 & 64 & Bukowina Tatrzańska (r) & 0.179 \\
\hline 2 & Węgierska Górka (r) & 0.776 & 65 & Zawoja (r) & 0.175 \\
\hline 3 & Krościenko nad Dunajcem (r) & 0.754 & 66 & Czorsztyn (r) & 0.175 \\
\hline 4 & Tymbark (r) & 0.692 & 67 & Tokarnia (r) & 0.124 \\
\hline 5 & Muszyna (u-r) & 0.684 & 68 & Grabów nad Pilicą (r) & 0.124 \\
\hline 6 & Krynica-Zdrój (u-r) & 0.637 & 69 & Nawojowa (r) & 0.091 \\
\hline 7 & Rabka-Zdrój (u-r) & 0.637 & 70 & Spytkowice (r) & 0.084 \\
\hline 8 & Jasienica Rosielna (r) & 0.608 & 71 & Czarny Dunajec (r) & 0.072 \\
\hline 9 & Garbatka-Letnisko (r) & 0.592 & 72 & Kiełczygłów (r) & 0.041 \\
\hline 10 & Gródek nad Dunajcem (r) & 0.577 & 73 & Czarna (r) & 0.041 \\
\hline 11 & Zagórz (u-r) & 0.560 & & &
\end{tabular}

Note: $\mathrm{r}$ - rural gmina, u-r - urban-rural gmina

Source: Author's calculation based on CSO LDB information.

The spatial distribution of development classes by the Measure 3 is presented in Fig. 4 .

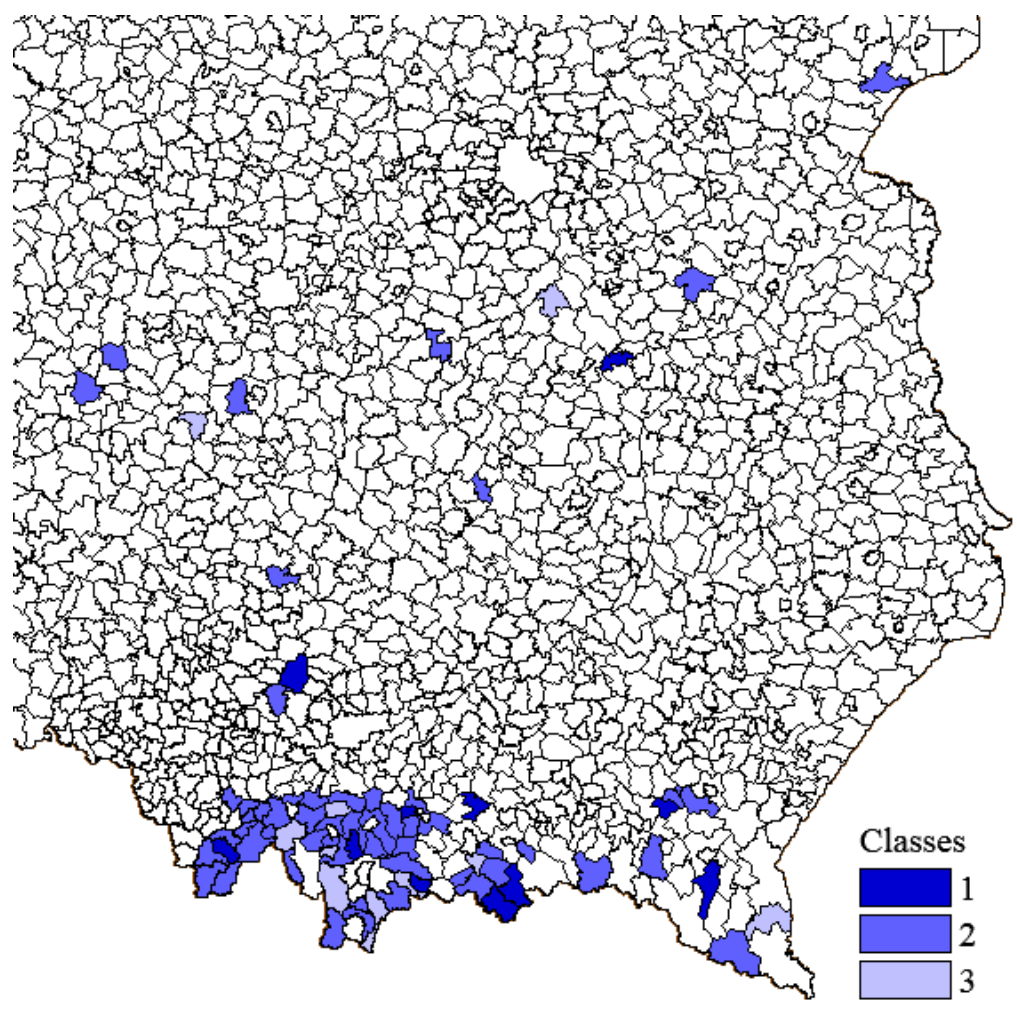

Fig. 4. Measure 3 - classes of government potential

Source: Author's calculation based on CSO LDB information. 
Important aspect of socio-economic development concerns local finances, its differentiation, availability as well as autonomy of spending. Therefore the Measure 4 combines three characteristics of a gmina: its own income per capita, its income for the EU projects realization per capita and its property investment expenditure per capita. They illustrate both economic situation of a gmina and level of activeness of local government.

As the analysis shows, 10 gminas have been found in the class of high development level, including four from Małopolskie Voivodship (Muszyna, Piwniczna-Zdrój, KrynicaZdrój, Łapsze Niżne), 5 from Śląskie Voivodship (Łękawica, Ślemień, Czernichów, Niegowa, Koszarawa) and Cisna from Podkarpackie Voivodship. The Class 3 included only 5 gminas: four from Małopolskie Voivodship (Budzów, Lubień, Kamionka Wielka, Raba Wyżna) and Krzywda from Lubelskie Voivodship (Table 5).

Table 5. Measure 4 - extreme classes of local finances structure

\begin{tabular}{|c|c|c|c|c|c|}
\hline Rank & Gmina & Value & Rank & Gmina & Value \\
\hline \multicolumn{3}{|c|}{ Class 1} & \multicolumn{3}{|c|}{ Class 3} \\
\hline 1 & Muszyna (u-r) & 0.643 & 69 & Budzów (r) & 0.115 \\
\hline 2 & Piwniczna-Zdrój (u-r) & 0.591 & 70 & Lubień (r) & 0.115 \\
\hline 3 & Łękawica (r) & 0.525 & 71 & Kamionka Wielka (r) & 0.105 \\
\hline 4 & Ślemień (r) & 0.490 & 72 & Raba Wyżna (r) & 0.092 \\
\hline 5 & Krynica-Zdrój (u-r) & 0.462 & 73 & Krzywda (r) & 0.091 \\
\hline 6 & Czernichów (r) & 0.451 & & & \\
\hline 7 & Cisna (r) & 0.413 & & & \\
\hline 8 & Niegowa $(r)$ & 0.358 & & & \\
\hline 9 & Łapsze Niżne (r) & 0.351 & & & \\
\hline 10 & Koszarawa (r) & 0.349 & & & \\
\hline
\end{tabular}

Note: $r$ - rural gmina, u-r - urban-rural gmina

Source: Author's calculation based on CSO LDB information.

The spatial distribution of development classes by the Measure 4 is presented in Fig.5.

The Measure 5 can be interpreted as a manifestation of activity of both communities (taking up self-employment, running social activity) and local authorities (incentives for foreign investors and local entrepreneurs). It aggregates 4 variables: number of national economy entities registered in REGON per 10,000 population, number of natural people running economic activity per 100 working-age population, number of foundations, associations and social organizations per 10,000 population and finally - number of newly registered entities per 10,000 working-age population. 


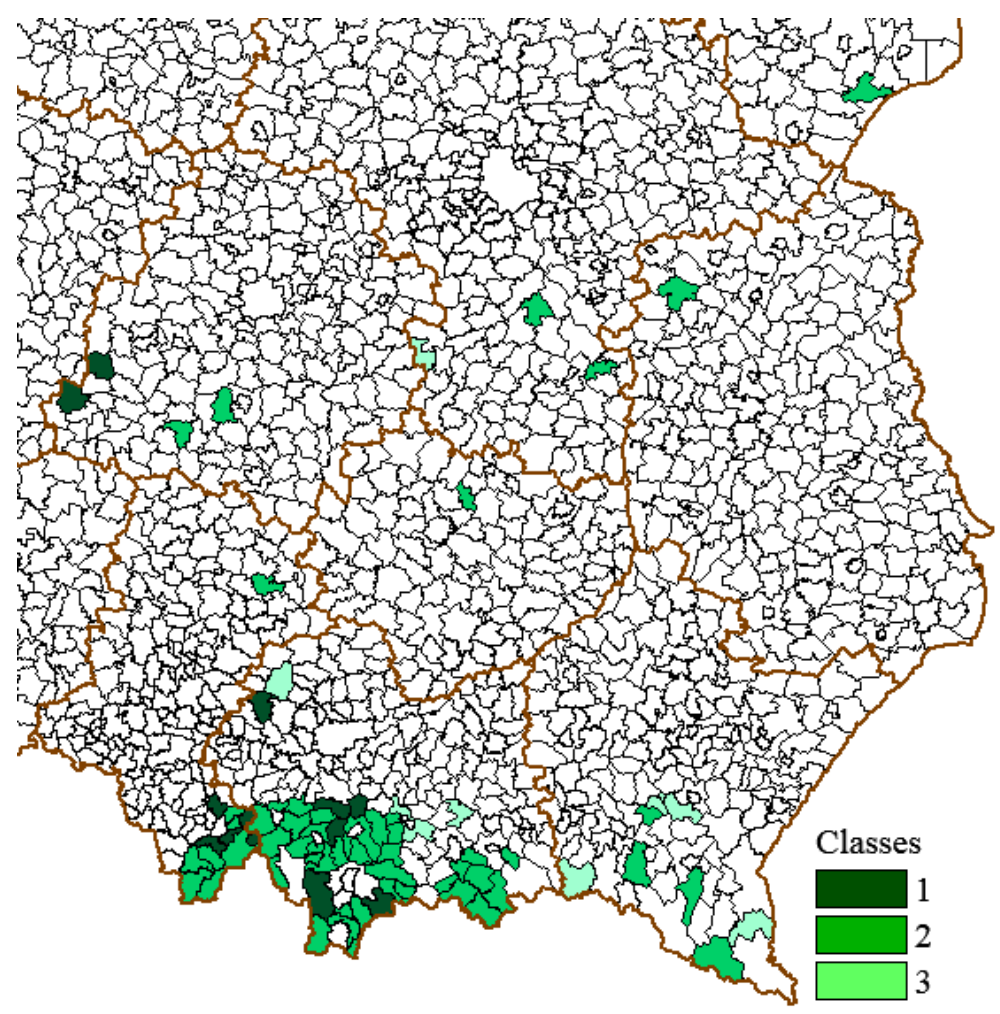

Fig. 5. Measure 4 - classes of local finances structure Source: Author's calculation based on CSO LDB information.

The top ten, creating the Class 1, includes two gminas from Podkarpackie Voivodship (Cisna, Czarna) and as many as 8 gminas from Małopolskie Voivodship: Krynica-Zdrój, Czorsztyn, Poronin, Krościenko nad Dunajcem, Kościelisko, Rabka-Zdrój, Ropa, Muszyna (Table 6). Most of them are very popular with tourists and spas' visitors.

Table 6. Measure 5 - extreme classes of entrepreneurship development

\begin{tabular}{cccccc}
\hline Rank & Gmina & Value & Rank & Gmina & Value \\
\hline \multicolumn{1}{c}{ Class 1 } & & & Class 3 & \\
\hline 1 & Cisna (r) & 0.650 & 66 & Spytkowice (r) & 0.103 \\
\hline 2 & Krynica-Zdrój (u-r) & 0.482 & 67 & Kluki (r) & 0.103 \\
\hline 3 & Czorsztyn (r) & 0.480 & 68 & Czarny Dunajec (r) & 0.099 \\
\hline 4 & Poronin (r) & 0.386 & 69 & Lipnica Wielka (r) & 0.095 \\
\hline 5 & Krościenko nad Dunajcem (r) & 0.361 & 70 & Krzywda (r) & 0.088 \\
\hline 6 & Kościelisko (r) & 0.343 & 71 & Nozdrzec (r) & 0.087 \\
\hline 7 & Rabka-Zdrój (u-r) & 0.341 & 72 & Lapsze Niżne (r) & 0.072 \\
\hline 8 & Ropa (r) & 0.340 & 73 & Domaradz (r) & 0.050 \\
\hline 9 & Czarna (r) & 0.331 & & & \\
\cline { 1 - 2 } 10 & Muszyna (u-r) & 0.320 & & &
\end{tabular}

Note: $\mathrm{r}$ - rural gmina, u-r - urban-rural gmina

Source: Author's calculation based on CSO LDB information.

On the contrary, the Class 3 groups four gminas from Małopolskie Voivodship (Spytkowice, Czarny Dunajec, Lipnica Wielka, Łapsze Niżne), two from Podkarpackie Voivodship (Nozdrzec, Domaradz) as well as Kluki (Łódzkie) and Krzywda (Lubelskie). 
The spatial distribution of development classes by the Measure 5 is presented in Fig.6.

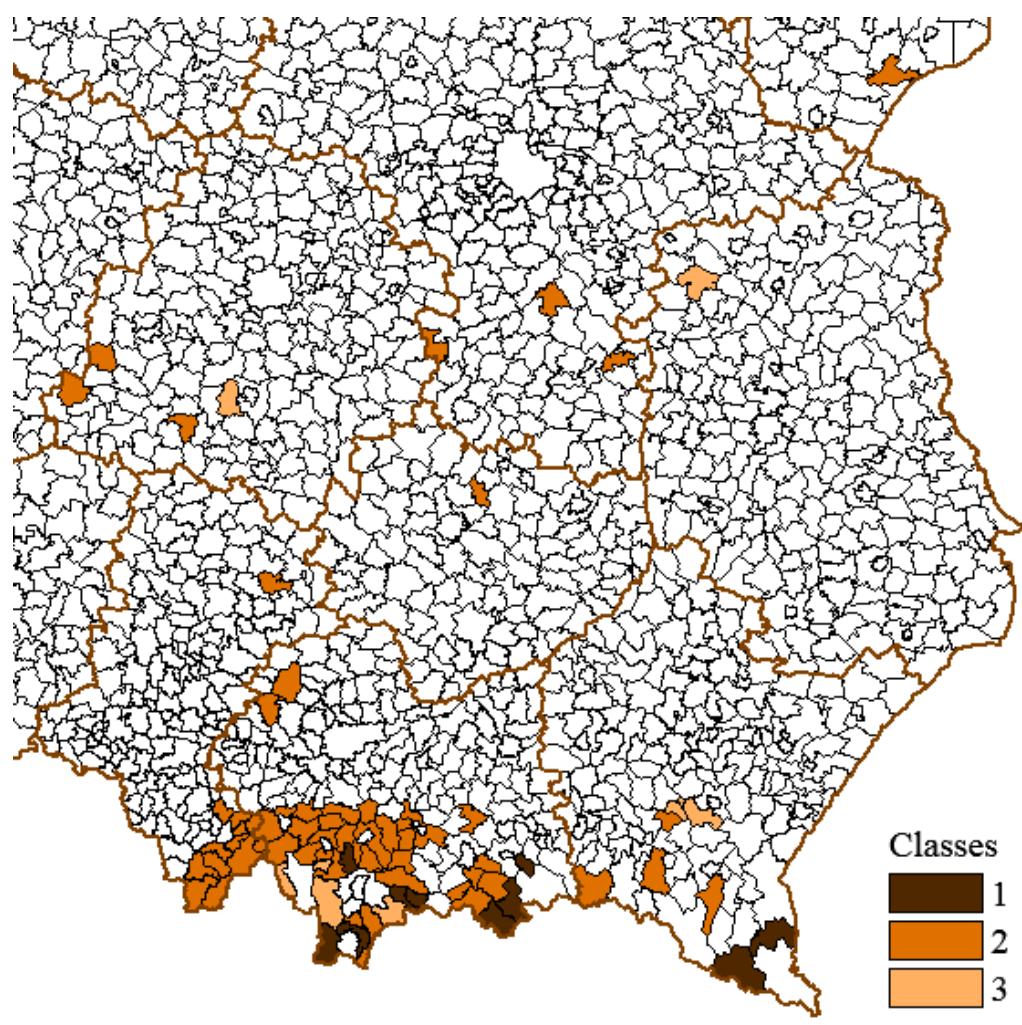

Fig. 6. Measure 5 - classes of entrepreneurship development Source: Author's calculation based on CSO LDB information.

Last measure - the Measure 6, informs about level of technical infrastructure development. It concerns two major technical aspects: availability of water supply network and sewerage network. Literature shows that other characteristics that can be used in construction of development rankings regard quality of local roads and access to gas supply. However, there is no current data on quality of local roads available for the LAU-2 level. With regard to gas supply - the network has been still highly underdeveloped in rural areas and comparing the small proportions (even fractions) does not make sense.

The Class 1 includes 6 gminas from Małopolskie Voivodship (Trzebinia, KrynicaZdrój, Olkusz, Czorsztyn, Muszyna, Poronin), 3 from Śląskie Voivodship (RadziechowyWieprz, Węgierska Górka, Łękawica) and Garbatka-Letnisko from Mazowieckie Voivodship. On the other hand, the class of low development level covers Gilowice (Śląskie) and as many as 8 gminas from Małopolskie Voivodship: Raba Wyżna, Bystra-Sidzina, Zawoja, Pcim, Tokarnia, Łabowa, Ropa, Budzów (Table 7).

The measure values for Ropa and Budzów have been negative. In Budzów, the water supply system was used by only $0.6 \%$ of the population, while the sewerage system $-0.2 \%$. In Ropa - these percentages amounted respectively to $5.3 \%$ and $1.1 \%$. In comparison, the average proportion of population with water supply network in all surveyed gminas amounted to $46.3 \%$ (median $43.3 \%$ ). Moreover, $35.3 \%$ of the population had connection to the sewerage system (median $33.2 \%$ ). 
Table 7. Measure 6 - extreme classes of technical infrastructure development

\begin{tabular}{cccccc}
\hline Rank & Gmina & Value & Rank & Gmina & Value \\
\hline & Class 1 & & & Class 3 & \\
\hline 1 & Trzebinia (u-r) & 0.918 & 65 & Gilowice (r) & 0.184 \\
\hline 2 & Krynica-Zdrój (u-r) & 0.861 & 66 & Raba Wyżna (r) & 0.179 \\
\hline 3 & Olkusz (u-r) & 0.854 & 67 & Bystra-Sidzina (r) & 0.161 \\
\hline 4 & Czorsztyn (r) & 0.827 & 68 & Zawoja (r) & 0.155 \\
\hline 5 & Radziechowy-Wieprz (r) & 0.667 & 69 & Pcim (r) & 0.140 \\
\hline 6 & Węgierska Górka (r) & 0.666 & 70 & Tokarnia (r) & 0.119 \\
\hline 7 & Garbatka-Letnisko (r) & 0.650 & 71 & Łabowa (r) & 0.103 \\
\hline 8 & Muszyna (u-r) & 0.648 & 72 & Ropa (r) & -0.002 \\
\hline 9 & Poronin (r) & 0.622 & 73 & Budzów (r) & -0.031 \\
\hline 10 & Lękawica (r) & 0.608 & & & \\
\hline
\end{tabular}

Note: $\mathrm{r}$ - rural gmina, u-r - urban-rural gmina

Source: Author's calculation based on CSO LDB information.

The spatial distribution of development classes by the Measure 6 is presented in Fig.7.

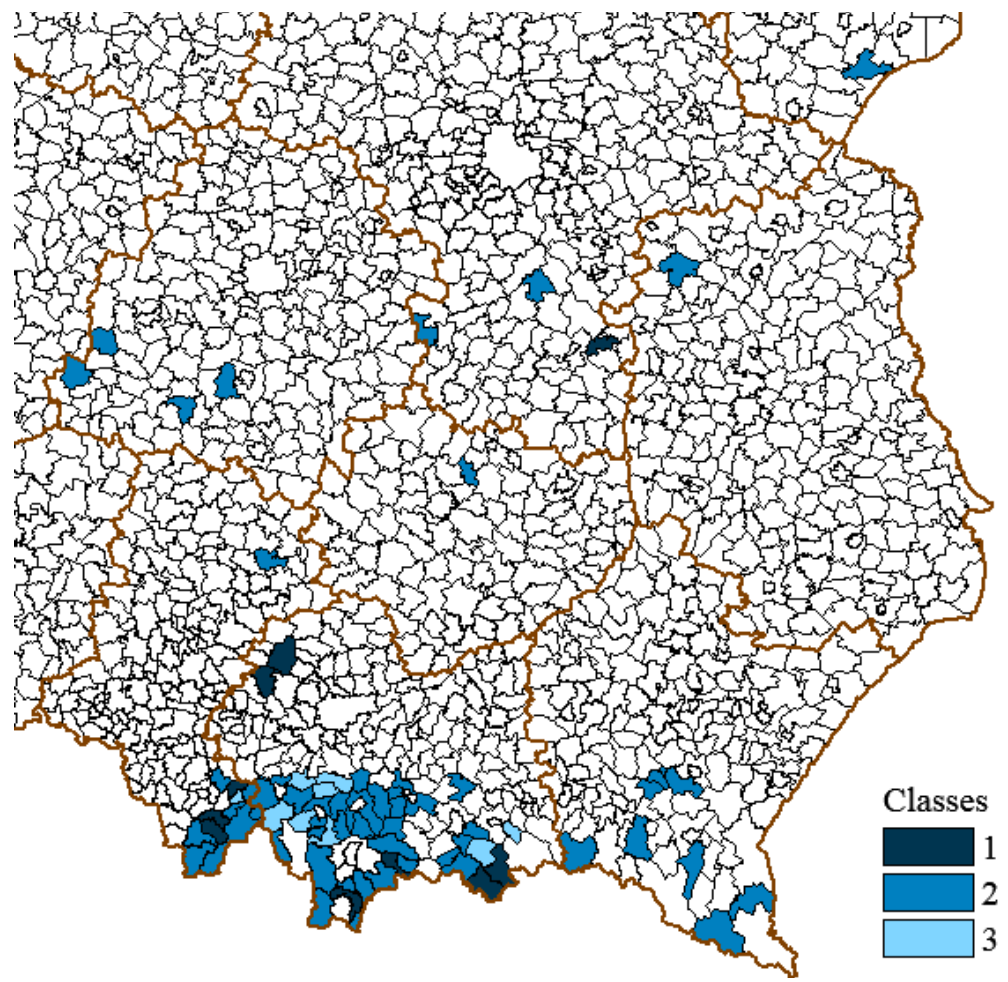

Fig. 7. Measure 6 - classes of technical infrastructure development Source: Author's calculation based on CSO LDB information.

\section{Socio-economic development level of agricultural most problem areas}

The class of high level of development has grouped 9 gminas from Małopolskie Voivodship (Krynica-Zdrój, Muszyna, Rabka-Zdrój, Trzebinia, Czorsztyn, Krościenko nad Dunajcem, Piwniczna-Zdrój, Tymbark, Kościelisko), 2 from Śląskie Voivodship (Czernichów, Węgierska Górka) and Cisna (Podkarpackie). 
On the other hand, the class of low level of development includes 3 Podkarpackie gminas (Krempna, Nozdrzec, Domaradz), 2 Mazowieckie gminas (Odrzywół, Grabów nad Pilicą), 2 Łódzkie gminas (Kluki, Kiełczygłów) as well as Krzywda (Lubleskie) and Kleszczele (Podlaskie).

Table 8. Extreme classes of socio-economic development of most problem agricultural areas

\begin{tabular}{cccccc}
\hline Rank & Gmina & Value & Rank & Gmina & Value \\
\hline \multicolumn{7}{c}{ Class 1 } & & & Class 3 & \\
\hline 1 & Krynica-Zdrój (u-r) & 0.386 & 65 & Odrzywół (r) & 0.078 \\
\hline 2 & Muszyna (u-r) & 0.383 & 66 & Krzywda (r) & 0.073 \\
\hline 3 & Cisna (r) & 0.380 & 67 & Kluki (r) & 0.070 \\
\hline 4 & Czernichów (r) & 0.296 & 68 & Krempna (r) & 0.067 \\
\hline 5 & Rabka-Zdrój (u-r) & 0.292 & 69 & Kiełczygłów (r) & 0.050 \\
\hline 6 & Węgierska Górka (r) & 0.279 & 70 & Grabów nad Pilicą (r) & 0.045 \\
\hline 7 & Trzebinia (u-r) & 0.274 & 71 & Nozdrzec (r) & 0.018 \\
\hline 8 & Czorsztyn (r) & 0.272 & 72 & Kleszczele (u-r) & 0.011 \\
\hline 9 & Krościenko nad Dunajcem (r) & 0.272 & 73 & Domaradz (r) & 0.008 \\
\hline 10 & Piwniczna-Zdrój (u-r) & 0.266 & & & \\
\hline 11 & Tymbark (r) & 0.255 & & & \\
\hline 12 & Kościelisko (r) & 0.243 & & & \\
\hline
\end{tabular}

Note: $\mathrm{r}$ - rural gmina, u-r - urban-rural gmina

Source: Author's calculation based on the CSO LDB information.

Krynica-Zdrój and Muszyna, which took the two first places in the final ranking, have been included in the classes of high development level in four detailed rankings: 3, 4, 5 and 6. Cisna, located on the third place, was classified as the Class 1 twice (Measures 4 and 5), but it also occurred once in the Class 3 (Measure 1). The class of high level of development included - in at least two rankings - following gminas: Czernichów (Measures 2 and 4) Rabka-Zdrój (Measures 3 and 5), Węgierska Górka (Measures 1, 3 and 6), Trzebinia (Measures 2 and 6 ), Krościenko nad Dunajcem (Measures 3 and 5) and Tymbark (Measures 1 and 3). Piwniczna-Zdrój took the $2^{\text {nd }}$ place in the ranking by the Measure 4 and Kościelisko $-6^{\text {th }}$ place by Measure 5 . On the other hand, Czorsztyn occurred twice in the Class 1 (Measures 5 and 6), but once in the Class 3 (Measure 3).

Even one presence in the Class 3 has been enough for gminas: Kluki (Measure 5), Krempna (Measure 2), Kleszczele (Measure 1), to be placed finally in the class of low level of development. Other gminas appear in Class 3 twice: Odrzywól - Measures 1 and 2; Krzywda - Measures 4 and 5; Kiełczygłów as well as Grabów nad Pilicą - Measures 1 and 3; Nozdrzec and Domaradz - Measures 2 and 5.

The spatial distribution of development classes by the final, aggregated measure is presented in Fig. 8. 


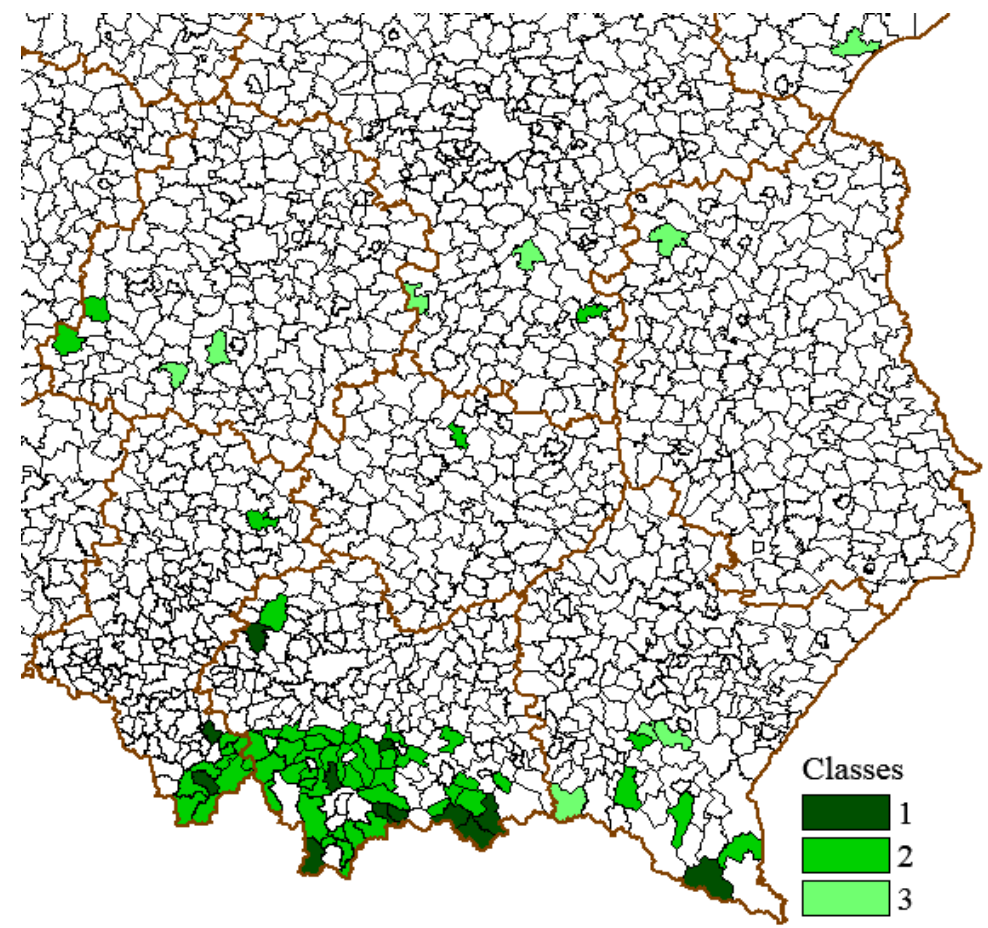

Fig. 8. Classes of socio-economic development of most problem agricultural areas Source: Author's calculation based on CSO LDB information.

Comparison of variables' average values shows that there is a great gap between the high-developed gminas and the low developed ones, especially concerning population density, birth rate, local government potential and finances as well as entrepreneurship development (Table 9).

Table 9. Comparison of variables' average values in the extreme classes of socio-economic development of most problem agricultural areas

\begin{tabular}{ccc}
\hline \multirow{2}{*}{ Variables } & \multicolumn{2}{c}{ Average values } \\
\cline { 2 - 3 } & Class 1 & Class 3 \\
\hline X1.1 & 140.7 & 48.0 \\
\hline X1.2 & 2.5 & -2.2 \\
\hline X1.3 & 25.6 & 32.4 \\
\hline X2.1 & 10.6 & 13.2 \\
\hline X2.2 & -5.0 & -9.6 \\
\hline X2.3 & 66.5 & 47.0 \\
\hline X3.1 & 42.1 & 20.1 \\
\hline X3.2 & 32.2 & 12.0 \\
\hline X4.1 & 1624.6 & 824.4 \\
\hline X4.2 & 388.7 & 147.3 \\
\hline X4.3 & 835.8 & 476.0 \\
\hline X5.1 & 971.6 & 517.9 \\
\hline X5.2 & 12.2 & 6.7 \\
\hline X5.3 & 34.8 & 30.8 \\
\hline X5.4 & 177.9 & 73.7 \\
\hline X6.1 & 55.1 & 73.3 \\
\hline X6.2 & 60.9 & 22.0 \\
\hline
\end{tabular}

Source: Author's calculation based on CSO LDB information. 


\section{Conclusions}

The specificity of mountain areas affects to a greater extent a decline in farms' productivity, reducing their competitiveness significantly related to freedom of choice of more profitable lines of production (Baran, 2008). In such areas with limited potential for proper agricultural production an important role should be played by non-agricultural functions. The analysis shows that the relatively higher level of development is observed in areas which are attractive for tourists - mountainous parts of Śląskie, Małopolskie and Podkarpackie Voivodships. Specificity of Polish mountain tourism enables receiving tourists throughout the year (see: Ostrowska, 2012; Musiał, 2008). It has been beneficial for development of local entrepreneurship, local employment and keeping young and educated people, which has a positive effect on rates of migration, population growth and favourable relation of population of working-age to population of post working-age.

\section{References}

Babuchowska, K., Kisiel, R. (2006), Wpływ samorządu lokalnego na lokalny rozwój gospodarczy na przykładzie gmin województwa warmińsko-mazurskiego, Acta Sci. Pol. Oeconomia 5(2), Warszawa.

Baran, E. (2008), Uwarunkowania przemian gospodarki górskiej w świetle procesów integracyjnych z UE, Problemy Zagospodarowania Ziem Górskich, Issue 55, KZZG PAN.

Chrzanowska, M., Drejerska, N., Pomianek, I. (2013), Analiza porównawcza poziomu rozwoju gmin wiejskich i miejsko-wiejskich województwa mazowieckiego w latach 2002 i 2009 z wykorzystaniem metody k-średnich, [in:] Problemy społeczno-ekonomiczne w uwarunkowaniach ryzyka i statystycznej nieokreśloności. Metody i modele w rozwoju regionów. Red. Włodzimierz Szkutnik Wydawnictwo Uniwersytetu Ekonomicznego w Katowicach, Katowice, pp. 9-21.

Czapiewski, K. Ł. (2010), Koncepcja wiejskich obszarów sukcesu społeczno-gospodarczego i ich rozpoznanie w województwie mazowieckim, Studia Obszarów Wiejskich, Vol. XXII, IGiPZ PAN, Warszawa.

Dziemianowicz, W., Swianiewicz, P. (ed.) (2007), Gmina pasywna, KPZK PAN, Warszawa.

Feltynowski, M. (2009), Ranking potencjału innowacyjnego polskich regionów zwykorzystaniem miar syntetycznych [in:] Nowakowska A. (ed.): Zdolności innowacyjne polskich regionów. Wydawnictwo Uniwersytetu Łódzkiego, Łódź.

Górka, J., Chmurska, M. (2004), Wykorzystanie wybranej metody taksonomicznej do klasyfikacji powiatów województwa wielkopolskiego na podstawie wybranych cech turystyczno-rekreacyjnych, Roczniki Naukowe AWF W Poznaniu, Issue 53.

Gralak, A. (2005), Poziom konkurencyjności wschodnich regionów Polski na tle zróżnicowań międzyregionalnych, Acta Sci. Pol. Oeconomia, 4(1), Warszawa.

Heffner, K., Rosner, A. (2002), Czynniki specyficzne wywierające wpływ na potencjał rozwojowy obszarów wiejskich, [in:] Rosner A. (ed.): Wiejskie obszary kumulacji barier rozwojowych, IRWiR PAN, Warszawa.

Hellwig, Z. (1968), Zastosowanie metody taksonomicznej do typologicznego podziału krajów ze względu na poziom rozwoju oraz zasoby i strukturę wykwalifikowanych kadr, Przeglad Statystyczny, No. 4, pp. 307-326.

Hellwig, Z. (1981), Wielowymiarowa analiza porównawcza i jej zastosowanie $w$ badaniach wielocechowych obiektów gospodarczych, [w:] Metody i modele matematycznoekonomiczne w doskonaleniu zarządzania gospodarką socjalistyczną, red. W. Welfe, PWE, Warszawa. 
Institute of Soil Science and Plant Cultivation (IUNG), Poland, available at: http://opr.iung.pulawy.pl/index.html?st=def, access: 03/22/2014.

Krakowiak-Bal, A. (2005), Wykorzystanie wybranych miar syntetycznych do budowy miary rozwoju infrastruktury technicznej, Infrastruktura i Ekologia Terenów Wiejskich, No. 3, PAN, Kraków, pp. 71-82.

Local Data Bank, Central Statistical Office, Poland, available at: http://www.stat.gov.pl/bdl/app/strona.html?p_name=indeks, access: 03/22/2014.

Misterek, W. (2011), Wykorzystanie instrumentów planowania strategicznego i operacyjnego w jednostkach samorzadu terytorialnego do pozyskiwania środków z funduszy UE, [in:] Węcławski J., Misterek W. (ed.): Uwarunkowania wykorzystania funduszy Unii Europejskiej przez jednostki samorządu terytorialnego w województwie lubelskim, Difin, Warszawa, pp. 83-99.

Musiał, W. (2008), Ekonomiczne i społeczne problemy rozwoju obszarów wiejskich Karpat Polskich, IRWiR PAN, Warszawa.

Nowak, E. (1990), Metody taksonomiczne w klasyfikacji obiektów społeczno-gospodarczych, PWE, Warszawa.

Ossowska, L. (2008), Natural conditions of development in rural areas of Middle Pomerania synthetic measurement, Journal of Agribusiness and Rural Development, No. 2(8), pp. 81-92.

Ostrowska, R. (2012), Wpływ scalenia gruntów na rozwój rolnictwa w terenach górskich, Infrastruktura i Ekologia Terenów Wiejskich, No. 1/III, PAN, Kraków, pp. 49-58.

Panek, T. (2009), Statystyczne metody wielowymiarowej analizy porównawczej, SGH, Warszawa.

Pietrzykowski, R. (2009), Regionalne zróżnicowanie województw po wstąpieniu Polski do Unii Europejskiej, Zeszyty Naukowe Szkoły Głównej Gospodarstwa Wiejskiego w Warszawie: problemy rolnictwa światowego, Vol. 9 (XXIV), Wydawnictwo SGGW, Warszawa, pp. 140-147.

Pomianek, I. (2010), Społeczno-ekonomiczne uwarunkowania rozwoju przedsiębiorczości na obszarach wiejskich (na przykładzie województwa warmińsko-mazurskiego), $\mathrm{PhD}$ dissertation manuscript, Faculty of Economic Sciences, Warsaw University of Life Sciences - SGGW.

Rakowska, J. (2009), Zmiany poziomu rozwoju gmin w Polsce w latach 2004 i 2008, [w:] Stawicki M. (ed.): Fundusze europejskie w gminach: rozwój lokalny, wykorzystanie środków UE, rekomendacje dla samorządów, Warszawa, pp. 282-287.

Rakowska, J. (2011a), Zmiany demograficzne na obszarach wiejskich Polski, Wieś Jutra, $11 / 12(160 / 161)$, pp. 7-10.

Rakowska, J. (2011b), Zróżnicowanie poziomu rozwoju gmin Polski Wschodniej, Roczniki Naukowe Stowarzyszenia Ekonomistów Rolnictwa i Agrobiznesu 2011, T. 13, z. 2, pp. 392-397.

Rosner, A. (2012), Zmiany rozkładu przestrzennego zaludnienia obszarów wiejskich. Wiejskie obszary zmniejszajace zaludnienie $i$ koncentrujace ludność wiejska, IRWiR PAN, Warszawa.

Rosner, A., Stanny, M. (2007), Zróżnicowanie poziomu rozwoju obszarów wiejskich w Polsce wedtug komponentu społecznego, [in:] Rosner A. (ed.): Zróżnicowanie poziomu rozwoju społeczno-gospodarczego obszarów wiejskich a zróżnicowanie dynamiki przemian. IRWiR PAN, Warszawa.

Surówka, A. (2007), Badanie zróżnicowania województw pod względem konkurencyjności, [in:] Woźniak M. G. (ed.), Nierówności społeczne a wzrost gospodarczy, Gospodarka oparta na wiedzy, No 11, Rzeszów, pp. 645-658. 
Tarka, D. (2013), Wpływ metody doboru cech diagnostycznych na wyniki klasyfikacji obiektów na przykładzie danych dotyczących ochrony środowiska, Prace Naukowe Uniwersytetu Ekonomicznego we Wrocławiu, No. 279, pp. 235-245.

Zimny, A. (2013), Rozwój społeczno-gospodarczy gmin podregionu konińskiego [in:] Fimińska-Banaszyk R., Zimny A. (ed.), Doskonalenie zarządzania w samorządach lokalnych, Wydawnictwo PWSZ w Koninie, Konin, pp. 89-116. 